\title{
Review \\ Ecological and Human Diet Value of Locusts in a Changing World
}

\author{
Gabriella J. Kietzka ${ }^{1, *(\mathbb{D})}$, Michel Lecoq ${ }^{2}\left(\mathbb{D}\right.$ and Michael J. Samways ${ }^{1}(\mathbb{D}$ \\ 1 Department of Conservation Ecology and Entomology, Stellenbosch University, \\ Stellenbosch 7600, South Africa; samways@sun.ac.za \\ 2 CIRAD, UMR CBGP, F-34398 Montpellier, France; mlecoq34@gmail.com \\ * Correspondence: gabikietzka@gmail.com; Tel.: +27-81-030-4491
}

Citation: Kietzka, G.J.; Lecoq, M.; Samways, M.J. Ecological and Human Diet Value of Locusts in a Changing World. Agronomy 2021, 11, 1856. https://doi.org/10.3390/ agronomy11091856

Academic Editor: Andrea Sciarretta

Received: 16 August 2021

Accepted: 9 September 2021

Published: 16 September 2021

Publisher's Note: MDPI stays neutral with regard to jurisdictional claims in published maps and institutional affiliations.

Copyright: (C) 2021 by the authors Licensee MDPI, Basel, Switzerland. This article is an open access article distributed under the terms and conditions of the Creative Commons Attribution (CC BY) license (https:// creativecommons.org/licenses/by/ $4.0 /)$.

\begin{abstract}
Since ancient times, locusts have been serious pests wreaking havoc on settled agriculture throughout much of the world. Numerous locust practices have been developed to control infestations. This has led to most commentaries portraying locust infestations only in a negative light while focusing on finding best management practices for suppressing locust populations and lessening crop damage caused by swarms. Yet, locusts are also of great ecological significance in being not only an extraordinary natural phenomenon but also major components of ecosystem nutrient cycling, arising long before settled agriculture. Furthermore, for humans, locusts are a nutritious food source, historically and currently being consumed directly. Locust control today should more regularly include their harvesting. This is now more feasible, as environmentally friendly biopesticides can be used to replace harmful organic pesticides. We focus here on the ecological significance of locusts by using calculations based on a $1 \mathrm{~km}^{2}$ area of swarming and breeding Desert locusts, Schistocerca gregaria, and show that the huge biomass of locust individuals contributes greatly to ecosystem processes while also having great potential use in human nutrition, especially where there is an urgent need for improved dietary intake and nutrition.
\end{abstract}

Keywords: Schistocerca gregaria; Desert locust; ecosystem processes; nutrient cycling; nutritional value

\section{Introduction}

"Their (locusts) disappearance ... would not interfere with any other food chain, because locusts are not the basic food of any other bird or beast. So, if we could invoke mystic powers and say, 'All locusts, be gone', I don't think this would make very much difference to world ecology" [1]. This statement by Haskell (1971), during his John Curtis 'Woodstock' Lecture on International Locust Research and Control, whether spoken out of bravado or ignorance, disregards the ecological significance of everything in nature, even locusts.

In the ancient Egyptian texts of the New Kingdom (1070-1550 BCE), locusts are positively referred to as the might of the Egyptian army while negatively as the defeated enemy armies, with 'locusts' being a metaphor for 'multitude' [2]. This double perspective has a biological equivalent: locusts as an extraordinary and ecologically important natural phenomenon yet also a harbinger of human hardship through resource loss and pestilence. A locust outbreak in the northwestern provinces, including Egypt, in the early fourth century is even thought to have led to an outbreak of rats (and their associated fleas) through an abundance of food provided by locust cadavers, which would have caused a devastating plague among the local human population [3].

A locust is a grasshopper (Orthoptera: Acrididae), normally solitarious but periodically displaying a massive increase in abundance, largely in response to changed and favorable weather conditions [4]. The great population increase is often associated with changes in its biochemistry, physiology, morphology, and behavior, known as densitydependent phase polyphenism [5]. The changed form often becomes nomadic, causing 
major economic damage to crop plants [5,6]. Although other insect species periodically increase to very high numbers and migrate, causing economic crop damage, it is the voracity of the polyphagous locust in both the young and adult stages, combined with gregarization and associated extremely high local biomass, that characterizes a locust plague.

Phylogenetically, phase polyphenism is not basal, with locusts arising from sedentary ancestors and the various phase-like traits, each having evolved in different contexts [7]. These contexts include isolation and climatic conditions. However, there can be loss of gregarization. The Desert locust, Schistocerca gregaria (Forskål), has its origin in the Old World [8], with the gregarious gregaria subspecies in the north of Africa, Arabia, and southwestern Asia, and the derived subspecies flaviventris, isolated in the south of the African continent, less gregarious and very rarely swarming [9]. This is possibly an adaptive response to climatic conditions experienced by the southern subspecies, which found no selective advantage for gregarization [7]. While the focus here is on the OldWorld Desert locust, we recognize that there are many locusts also present in the New World, with indications that some of these at least have been eaten by indigenous peoples. Space precludes here the detailing of these other species in human nutrition, we strongly recommend that further studies consider the nutritional opportunities provided by them.

Globally, there are several species of grasshoppers that currently, or at some time in the past, have shown a tendency towards gregarization and caused economic damage (Table S1). Many of these still do. Some species occur as different subspecies at different geographical locations and vary in their behavior and morphology. While we generally view locusts as having a major negative impact on human activities, they are also of great ecological significance, having periodic and localized intense effects on local ecosystems. These effects can ostensibly be negative, such as massive herbivore pressure on crops or even indigenous plants, or be positive, as through deposition of nutrients to new locations. Here, we review the ecological significance of locusts, past and present. We focus on the infamous Desert locust, using it to sketch how locust swarms move nutrients over space and time, specifically the cycling of nitrogen and carbon into the soil ecosystem for plant uptake and their nutritional value as food for humans.

\section{Background: Biology and Ecology of Locusts}

\subsection{Abiotic and Biotic Drivers of Locust Outbreaks}

A combination of interacting factors is responsible for locust outbreaks. Winds of a particular strength and direction enable adult locusts to assemble [10,11]. In dry climatic zones, the formation of locust swarms is associated with heavy and extensive rainfall events, as occurred on the horn of Africa and in East Africa (2019-2020). When these adults converge on localized patches of green vegetation appearing after rains, they form large congregations [12]. Adults then select suitable oviposition sites [13], with salinity and soil moisture, up to $5 \mathrm{~cm}$ below the surface, being important abiotic variables [14]. In areas where vegetation and oviposition resources are discontinuous, solitarious adults will aggregate where resources are concentrated. This is to a lesser extent when resources are of poor quality and evenly spread across the landscape [15]. Plant community characteristics also play a major role in determining the possibility of an outbreak [16]. High rainfall enables vigorous vegetation growth, which supports high locust population growth in dry areas $[17,18]$. Once eggs have hatched, and when nymphs are densely crowded, mutual tactile stimulation of the hind legs increases their serotonin levels [19], which leads directly to changes in behavior and, in the following generations, to color and morphological changes, higher appetite, and increased intensity of breeding [20,21].

\subsection{Anthropogenic Drivers}

Various anthropic actions can promote locust outbreaks, and there is increasing evidence on the impact of human activity [22]. Environmental changes in West Africa appear to be responsible for the increased economic importance of Zonocerus variegatus [23]. Overgrazing, by creating favorable conditions for gregariousness, is a common cause of 
outbreaks of certain species such as the Moroccan locust (Dociostaurus maroccanus) [24,25]. For some species, such as the Italian locust, Calliptamus italicus, the abandonment of cultivated fields can result in huge outbreaks [26]. In northern China, intensive grazing and subsequent degradation of grasslands favor outbreaks of Oedaleus asiaticus, probably by reducing the protein content of plants [27]. In Australia, outbreaks of Austroicetes cruciata and Chortoicetes terminifera may have resulted from ecological changes following the introduction of European livestock and agriculture [28]. In southeastern Asia, Locusta migratoria outbreaks are normally inhibited by the humid tropical environments. However, deforestation in the area is adversely synergistic with drought conditions favoring swarming and greatly elevated population levels [29]. Solitarious individuals of Schistocerca gregaria on the Sudan Red Sea coast especially congregate in the sandy, high-nitrogen-containing, moisture-retaining soils of wadies, and where Millet (Panicum turgidum) and the intercrop Heliotropium arbainense are grown. These agricultural landscapes constitute $<5 \%$ of the total area but are significant sources of locust outbreaks [16].

\subsection{Historical and Current Control Methods}

Figure 1 summarizes some commonly used traditional and new control methods. Current evidence suggests that before pesticides, locusts were controlled by mechanical or other physical means. Some techniques include setting fire to roosting adults, trampling or chasing hoppers and burying them in trenches, and plowing known locust egg beds. These traditional methods do not require specialized equipment, are low-cost, and do not adversely impact the environment. However, they are labor intensive, time consuming, and often ineffective [30].

\section{Mechanical and chemical control methods}

-Make fires or noise to prevent adult swarms from settling

- Cover roosting sites with straw and burn

- Chase hoppers into trenches and bury, burn or drown them

- Trample or use branches to beat hoppers

- Plough or dig up egg pods at ovipositionsites

-Apply neem and linseed oils to prevent locusts from swarming and to damage their antennae

-Use garlic as a deterrant

- Apply a thin layer of flour to crops to gum up locust mouth parts

-Instigate cover crops with nets sprayed with neem oil or garlic

- Baiting: mix insecticide dust with a carrier (bran or maize) and scatter around locust swarms

-Dusting: mix insecticidedust with a powder (chalk or talcom) and scatter, or fill a hesian bag with mixture and beat with a stick to apply

- Spraying: most common method, uses a sprayer to atomize and apply a liquid pesticide

-Ultra-low volume(ULV) spraying: newest technology, small droplets that are oil based

-Drones for ULV spraying

Figure 1. Popular past and present mechanical and chemical control methods used to control locust swarms and bands.

Sodium fluorosilicate and sodium arsenate were the first chemical controls used in India in the 1800s. Dusting and, to a greater extent, baiting were the first means of insecticide application. In the 1940s, the organochlorines benzene hexachloride (BHC) and dieldrin were introduced. These were applied by spraying, initially on the ground, and 
then in 1951, the first aerial application of dieldrin was trialed on a Desert locust swarm. In the 1970s, these persistent organochlorines and alike were banned, and a global shift towards, mainly, organophosphates, such as fenitrothion and malathion, occurred, which are still used today in addition to a few others (benzoylurea, carbamate, pyrethroid, and phenyl pyrazole) [31].

Later technology allowed for biological control agents, for example the protozoan, Nosema locustae [32], and the synthesis of biopesticides, which are developed from various strains of the entomopathogenic fungi, Metarhizium acridum [33]. These are not known to be harmful to humans, and to date have not been detected as adverse to biodiversity or environmental health. A major obstacle inhibiting extensive utilization of the fungi is that locusts only begin to die five days post-spray, with maximum mortality occurring one to two weeks post-application. Even so, the credibility of biopesticides for locust management programs is increasingly being recognized [22,34]. While the application of pathogens like entomopathogenic fungi and nematodes from an environmental point of view are preferable to synthetic organic pesticides, there must be some consideration of possible side-effects on other species, especially rare and threatened insects. This requires urgent further assessment and monitoring.

The latest spraying technique uses a much smaller volume of liquid, referred to as ultra-low-volume (ULV) spraying. The formulation of ULV is oil based to prevent the small droplets from evaporating, and specialized sprayers are used to ensure the insecticide is applied efficiently and safely. These have been designed to accommodate all application methods and can be carried or mounted on a motor vehicle or on an airplane or helicopter [35,36]. Recent projects have developed and begun testing Metarhizium products in an oil form to make them suitable for ULV application [35-37]. Today, geographical positioning systems (GPS) on ground vehicles are used for precise pesticide application, following drone flyovers for early detection of locust swarm formation and for rapid application of ULV sprays $[37,38]$. However, much research is still needed to evaluate the effectiveness of these methods under a range of circumstances.

\section{Locusts in a Changing World}

\subsection{The Desert Locust (Schistocerca gregaria) as an Example}

The Desert locust reproduces rapidly and migrates over very long distances. It has the genetic predisposition to exist in two forms, solitaria or gregaria [4,39]. During recessions, solitary Desert locusts are usually restricted to the semiarid and arid deserts of Africa and the Near East and Southwest Asia that receive less than $200 \mathrm{~mm}$ of rain annually. This covers an area of about 15 million $\mathrm{km}^{2}$, consisting of about 30 countries [40]. During the invasion periods, approximately 31 million $\mathrm{km}^{2}$ and over 60 countries are recurrently vulnerable to Desert locust swarms, affecting up to $20 \%$ of the world's land area [41]. For these reasons, the Desert locust is considered the most dangerous migratory pest in the world. There is an abundance of information available on this pest, which makes it the ideal species to use as an example for quantifying the ecological significance and nutritional value to humans. Here, characteristics related to the Desert locust and its swarming dynamics were used for the objectives listed in Figure 2.

Table 1 summarizes the characteristics used for calculations, acquired from a variety of sources. It was evident from the literature that there is great variability in Desert locust (and other species) swarm dynamics, biological characteristics, and morphological traits. Therefore, the tables and subsequent calculations provided here serve as examples and are subject to change according to the resources, region, and subspecies used.

For the calculations that follow, a $1 \mathrm{~km}^{2}$ area of 60 million adult Desert locusts was used. This was based on the average density of a swarm in Kenya in 1955 and resembles average swarm densities from other resources [42,43]. For each objective, unique assumptions are stated, but all calculations assumed: (1) locusts lived for the average (113 days) adult life span; (2) hopper instar stages 1 to 4 lasted 6.5 days each, and stage 5 lasted 10 days; 
(3) the swarm comprised a 1:1 ratio of males to females; and (4) hoppers were evenly divided between the five instar stages.

Determine the quantity of food consumed by $1 \mathrm{~km}^{2}$ of adult locusts and their progeny

- Food consumed by 1 swarming desert locust during its adult life span

- Number of hoppers produced by $1 \mathrm{~km}^{2}$ of adult swarming locusts

- Food consumed by $1 \mathrm{~km}^{2}$ of adults, settling density 60 million $/ \mathrm{km}^{2}$

-Food consumed by hoppers, accounting for mortality and differences between instar stages

Determine value of locust cadavers and frass for nutrient cycling (nitrogen and carbon)

-Weight of frass produced per adult over adult life span

-Weight of frass produced per hopper at each instar

-Weight of nymph cadavers based on mortality at each instar

- Nitrogen and carbon cycled by $1 \mathrm{~km}^{2}$ of adult locusts and their progeny

- Relate nutrients cycled to rice and maize plant intake and production for human consumtion

Determine the nutritional value of $1 \mathrm{~km}^{2}$ of adult locusts and their progeny

- Body weight of $1 \mathrm{~km}^{2}$ of adults, 60 million individuals

- Body weight of their progeny at various instar stages

- Calculate mineral content based on body weights

- Relate mineral content to human nutritional needs based on adult daily recommended intake

Figure 2. Main objectives and calculations relating to the Desert locust (S. gregaria).

Table 1. Main parameters of the Desert locust (S. gregaria) in its swarming phase.

\begin{tabular}{|c|c|}
\hline Factor & Value \\
\hline \multicolumn{2}{|l|}{ Adults } \\
\hline Adult body length & $\begin{array}{l}\text { F: } 5 \text { to } 6 \mathrm{~cm}(5.5 \mathrm{~cm}) \\
\text { M: } 4.5 \text { to } 5 \mathrm{~cm}(4.75 \mathrm{~cm})[43]\end{array}$ \\
\hline Adult body weight & $\begin{array}{l}\text { F: } 3.5 \mathrm{~g}, \mathrm{M}: 2.2 \mathrm{~g} \\
\text { Avge: } 2.85[43]\end{array}$ \\
\hline Daily food consumption & Own body weight [44] \\
\hline Adult duration life stage & $\begin{array}{l}\text { Min: } 75 \text { days, Max: } 150 \text { days } \\
\text { Avge: } 113 \text { days [43] }\end{array}$ \\
\hline \multicolumn{2}{|l|}{ Swarms } \\
\hline Locust density settling & $\begin{array}{l}\text { Avge: } 60 \text { million } / \mathrm{km}^{2} \text { (patchy vegetation) [42] } \\
\text { (Average density settled swarm in Kenya 1955) }\end{array}$ \\
\hline Flight speed & $\begin{array}{l}\text { Range: } 3.8-4.3 \mathrm{~m} / \mathrm{s} \text { and } 3 \mathrm{~m} / \mathrm{s} \text {, Avge: } 3.5 \mathrm{~m} / \mathrm{s} \\
=12.6 \mathrm{~km} / \mathrm{h}[45]\end{array}$ \\
\hline Daily flight period & Min: 9-10 h, Max: 13-20 h, Avge: 14.5 h [43] \\
\hline \multicolumn{2}{|l|}{ Eggs } \\
\hline Number of times female lays & 2-3, Avge: $2[43]$ \\
\hline Eggs per pod (1st, 2nd and 3rd laying) & $60-80(1), 50-70(2), 35-70$ (3), Avge: 70, 60, 52.5 [43] \\
\hline Eggs per generation & 140 per female $[43]$ \\
\hline Egg pod density & $200-500 / \mathrm{m}^{2}$ in groups, Avge: $350 / \mathrm{m}^{2}$ in groups [43] \\
\hline Pod length & $3-4 \mathrm{~cm}[43]$ \\
\hline Egg mortality & Avge: $33 \%[43]$ \\
\hline Egg weight & Avge: 5.92 mg [46] \\
\hline Pod weight & Avge: 536.8 mg [46] \\
\hline \multicolumn{2}{|l|}{ Hoppers } \\
\hline Number of instars & $5[43]$ \\
\hline Nymph body lengths (mm) & 7 (S1), 15 (S2), 20 (S3), 33 (S4), 50 (S5) [43] \\
\hline Nymph body weights (mg) & $\begin{array}{l}30-40(\mathrm{~S} 1), 50-80(\mathrm{~S} 2), 120-200(\mathrm{~S} 3), 500-700(\mathrm{~S} 4), 1000-1200 \\
\text { (S5), Avge: } 35,65,160,600,1100[43]\end{array}$ \\
\hline Daily food consumption & Own body weight [43] \\
\hline Duration of stages & S1-S4: 6-7 days, Avge: 6.5 days, S5: 10 days [43] \\
\hline Mortality & $70 \%$ (S1), 20\% (S2), 10\% (S3-S5) [43] \\
\hline
\end{tabular}


The ecological effects of locust outbreaks are poorly researched. To sustainably manage ecosystems affected by locust outbreaks, a clear understanding of how locusts influence ecosystem function and structure is required. Two of the most obvious but opposing effects are (1) locust swarms rapidly reduce plant aboveground biomass and can suppress plant growth. (2) However, they also play an important role in nutrient cycling [47,48]. During outbreaks, locust frass and cadavers land on the soil, and as organic detritus, they are decomposed by microorganisms. Nutrients, such as nitrogen and carbon, are released into the soil and are available for plant uptake [7,49]. The damage caused by a swarm of locusts as well as the nutrients they give back will not be confined to an area. The daily distance traveled by an adult swarm of Desert locusts is around $183 \mathrm{~km} / \mathrm{d}$, which is based on the average flight speed and average daily flight period (Table 1). A quarter degree is equal to $30 \mathrm{~km}^{2}$, which means a swarm will move approximately 6.1 quarter degrees in a day. This can be used to calculate how long it will take a swarm to reach a certain area on any map.

\subsection{Food Consumed by $1 \mathrm{~km}^{2}$ of Adult Locusts and Their Progeny}

Calculations adhered to the previously mentioned assumptions. Throughout their adult life stage, female locusts consume more than male locusts (395 $\mathrm{g}$ and $249 \mathrm{~g}$, respectively), but the average of the two, $332 \mathrm{~g}$, was used in line with a 1:1 sex ratio (Tables 1 and 2). Considering each instar duration and body weight, an individual nymph was estimated to overall consume $16.59 \mathrm{~g}$ of food (Tables 1 and 2). Over the entire life span of a Desert locust, it is estimated to consume roughly $339 \mathrm{~g}$ of food. To put these values into perspective, using a locust density of 60 million $/ \mathrm{km}^{2}$, around 2.814 billion hoppers would be produced. This is based on the assumptions that half of the population are female, each female will produce 140 eggs, and egg mortality is 33\% (Table 1). In one generation, with mortality at each instar accounted for, and occurring halfway through the stage, hoppers $(7,941,799 \mathrm{~kg})$ and adults $(18,240,000 \mathrm{~kg}$ ) would consume $26,182 \mathrm{t}$ of plant material (Table 2).

Table 2. Food consumption estimates by adult Desert locusts and their progeny in $1 \mathrm{~km}^{2}$ area of 60 million adults.

\begin{tabular}{cc}
\hline Variable & Measure \\
\hline Average food consumed by 1 adult locust & $322 \mathrm{~g}(\mathrm{~F}: 395 \mathrm{~g})(\mathrm{M}: 249 \mathrm{~g})$ \\
Food consumed by 1 nymph (all instars) & $16.59 \mathrm{~g}$ \\
Average food consumed by 1 locust & $338.59 \mathrm{~g}=339 \mathrm{~g}(\mathrm{~F}: 411.59 \mathrm{~g})(\mathrm{M}: 265.59 \mathrm{~g})$ \\
Number of nymphs produced by adults & 2.814 billion hoppers \\
Food consumed by 1 km² of adults & $18,240,000 \mathrm{~kg}$ \\
Food consumed by their progeny & $7,941,799 \mathrm{~kg}$ \\
Food consumed by adults and progeny & $26,181,799 \mathrm{~kg} \approx 26,182 \mathrm{t}$ \\
\hline
\end{tabular}

We now consider the ecological value of the Desert locust in terms of its involvement in nutrient cycling. We do this using two objectives: (1) plant food consumed by both adult and young locusts per unit land area $\left(1 \mathrm{~km}^{2}\right)$, and (2) the delivery of nutrients to the same land surface area via locust cadavers and frass.

\subsection{The Value of Locust Cadavers and Frass for Nitrogen and Carbon Cycling}

The effect of locust swarms on nitrogen cycling is dependent on the quantity of nitrogen in their frass and cadavers, as well as on the time it takes to become available to plants. Through consuming vegetation, locusts divert nitrogen from plants to the soil, and as a result, soil mineral nitrogen can be greater than in the absence of locust invasions [47]. However, if nitrogen is mineralized too rapidly it can be leached and lost from the ecosystem [48]. Sometimes when locusts infest cultivated crops, such as wheat, they may preferentially feed on broad-leaved weeds in the vicinity, which can result in a net transfer of nitrogen from the weeds to adjacent crop plants [49]. 
The response of plants to defoliation by locusts depends somewhat on the availability of nitrogen [50]. The speed with which nitrogen in locust cadavers and frass become available affects the plants' ability to regrow after defoliation. If nitrogen is rapidly mineralized, it could be available to plants in the same season and aid in their recovery post locust outbreak. Alternatively, nitrogen will be slowly available if it is immobilized or recalcitrant and will likely favour plants that are more efficient users or better competitors for soil nitrogen [47].

Calculations adhere to the aforementioned assumptions: data on adult cadavers were obtained from Fielding et al. [47] and based on the species Melanoplus borealis and Chorthippus curtipennis. Importantly, species nitrogen and carbon contents did not differ between species cadavers. Adult locust cadaver weights were assumed to be the average male and female body weights [43] (Table 1). Frass weights for adult Desert locusts were averaged from two different studies, for females Hill et al. [51] and males Norris [52]. Frass nutrient composition is dependent on diet, among other factors, and averages from the data were used and comprised a range of diets from laboratory-raised and free-range specimens [47]. For hoppers, it was assumed they produce the same weight of frass each day equal to their body weight for each instar, and each stage lasted the average number of days (Table 1). For adult locusts, all were assumed to die and contribute to cadaver weight. For hopper frass and cadaver weight calculations, mortality was accounted for at each stage and presumed to occur halfway through the stage to account for the spread of deaths over time, and carbon $(\mathrm{C})$ and nitrogen $(\mathrm{N})$ content and mineralization were the same as for adults $[43,47]$. Percentage of $C$ in frass and cadavers was calculated using the $\mathrm{C} / \mathrm{N}$ ratio (Table 3 ).

Table 3. Percentages of nitrogen $(\mathrm{N})$ and carbon $(\mathrm{C})$ content in locust frass and cadavers and percentages mineralized after 28 days.

\begin{tabular}{cccccc}
\hline Source & \%N & $\mathbf{C} / \mathbf{N}$ & \%C & \%N Mineralized & \%C Mineralized \\
\hline Frass & 2.7 & 16.99 & 45.87 & 10.83 & 27.17 \\
Cadavers & 10.7 & 4.3 & 46.01 & 44 & 44 \\
\hline
\end{tabular}

Content of $\mathrm{N}$ found in locust frass was $2.7 \%$ and $10.7 \%$ for cadavers, and of that, $10.83 \%$ and $44 \%$ were mineralized within 28 days, respectively (Table 3 ). Carbon content of locust frass was $45.87 \%$ and $46.01 \%$ for cadavers, and of that, $27.17 \%$ and $44 \%$ were mineralized, respectively (Table 3). Throughout the average adult life stage, 113 days, a female adult produces $32 \mathrm{~g}$ of frass and a male $23 \mathrm{~g}$. Their cadavers, which are equal to their average body weights, are $3.5 \mathrm{~g}$ and $2.2 \mathrm{~g}$, respectively (Tables 1 and 4). A hopper that survived all instar stages produces $16.59 \mathrm{~g}$ of frass (Table 4). The weight of frass and cadavers produced by 60 million adult Desert locusts and their progeny is estimated around $9756 \mathrm{t}$ (Table 4). Of the total weight, around 276,502 $\mathrm{kg}$ of $\mathrm{N}$ and 44,475,093.50 kg of $\mathrm{C}$ would be transferred (Table 4). After incubation in soil for 28 days at $15{ }^{\circ} \mathrm{C}$ (near the average growing season soil temperature in central Alaska [47]), approximately $35,758 \mathrm{~kg}$ of $\mathrm{N}$ and $1,228,562.18 \mathrm{~kg}$ of $\mathrm{C}$ would be mineralized (Table 4 ). 
Table 4. Weights and nutrient cycling dynamics, nitrogen $(\mathrm{N})$ and carbon $(\mathrm{C})$ of $1 \mathrm{~km}^{2}$ of adult Desert locusts and their progenies.

\begin{tabular}{|c|c|}
\hline Variable & Value \\
\hline Weight of frass produced by 1 adult locust & $\mathrm{F}: 32 \mathrm{~g}, \mathrm{M}: 23 \mathrm{~g}$ \\
\hline Weight of adult cadaver & F: $3.5 \mathrm{~g}, \mathrm{M}: 2.2 \mathrm{~g}$ \\
\hline Weight of frass produced by 1 hopper & $16.59 \mathrm{~g}$ (S1: $0.23 \mathrm{~g}, \mathrm{~S} 2: 0.42 \mathrm{~g}$, S3: $1.04 \mathrm{~g}, \mathrm{~S} 4: 3.9 \mathrm{~g}, \mathrm{~S} 5: 11 \mathrm{~g})$ \\
\hline Weight of hopper cadavers (all stages) & (S1: 0.035 g, S2: 0.065 g, S3: 0.16 g, S4: 0.6, S5: 1.1$)$ \\
\hline \multicolumn{2}{|l|}{$1 \mathrm{~km}^{2}$ area of adult locusts } \\
\hline Weight of frass from adults & $1,650,000 \mathrm{~kg}$ \\
\hline $\mathrm{N}$ from frass of adults, $\mathrm{N}$ mineralized & 44,550 kg, mineralized: $4824.77 \mathrm{~kg}$ \\
\hline $\mathrm{C}$ from frass of adults, $\mathrm{C}$ mineralized & $756,855 \mathrm{~kg}$, mineralized: $205,637.50 \mathrm{~kg}$ \\
\hline Weight of cadavers from adults & $17,100 \mathrm{~kg}$ \\
\hline $\mathrm{N}$ from cadavers of adults, $\mathrm{N}$ mineralized & 1829.7 kg, mineralized: $805.07 \mathrm{~kg}$ \\
\hline $\mathrm{C}$ from cadavers of adults, $\mathrm{C}$ mineralized & $7867.1 \mathrm{~kg}$, mineralized: $3461.79 \mathrm{~kg}$ \\
\hline \multicolumn{2}{|l|}{ Progeny of $1 \mathrm{~km}^{2}$ area of adult locusts } \\
\hline Weight of hopper frass & $7,941,798 \mathrm{~kg}$ \\
\hline $\mathrm{N}$ from frass of hoppers, $\mathrm{N}$ mineralized & 214,428.55 kg, mineralized: 23,222.61 kg \\
\hline C from frass of hoppers, $\mathrm{C}$ mineralized & $3,642,902.74 \mathrm{~kg}$, mineralized: $989,776.68 \mathrm{~kg}$ \\
\hline Weight of hopper cadavers & $146,671 \mathrm{~kg}$ \\
\hline $\mathrm{N}$ from hopper cadavers, $\mathrm{N}$ mineralized & $15,693.80$ kg, mineralized: $6905.27 \mathrm{~kg}$ \\
\hline $\mathrm{C}$ from hopper cadavers, $\mathrm{C}$ mineralized & $67,468.66 \mathrm{~kg}$, mineralized: $29,686.21 \mathrm{~kg}$ \\
\hline Overall N, overall N mineralized & $276,502.05 \mathrm{~kg}$, mineralized: $35,757.72 \mathrm{~kg}$ \\
\hline Overall C, overall C mineralized & $4,475,093.50 \mathrm{~kg}$, mineralized: $1,228,562.18 \mathrm{~kg}$ \\
\hline
\end{tabular}

\subsection{Nutritional Value of Locusts for Human Food}

Locust swarms are mostly viewed as negative events. However, from a human food perspective, they have great potential, with a long history of locusts used as food. Entomophagy is the ancient practice of humans eating insects. As early as $2000 \mathrm{BC}$, there is evidence of letters written to kings of the Middle East that reported the consumption of locusts, in particular the Desert locust [41]. The Old Testament describes one of the first acceptable uses of insects as food and permits the consumption of 'the locust of any kind, the bald locust of any kind, the cricket of any kind, and the grasshopper of any kind' (Leviticus 11:22; [53]). Historically, locusts were seen as a delicacy consumed by the social elite, for example, on a Neo Assyrian palace relief slab, from the eighth century BC, skewered locusts are being presented to a royal banquet. In William Shakespeare's tragedy Othello, assumed to be written in 1603, locusts are referred to as a delicacy: Othello $(1,3)$, Iago: "The food that to him now is as luscious as locusts shall be to him shortly as bitter as coloquintida." Furthermore, Queen Ranavalona II (1829-1883) of Madagascar indulged in locusts collected by her servants [41]. Even in the New Testament, locusts were depicted as a delicacy, when John the Baptist is 'preaching in the wilderness of Judea,' wearing 'a garment of camel hair and a leather belt around his waist' and eating 'locusts and wild honey' (Matthew 3:4; [53]. Traditionally, the Khoisan of southern Africa also ate grasshoppers and locusts, after roasting them on grills, as depicted in a painting by Samuel Daniell in 1805 (Figure 3a) [54]. In Brazil, the Nambikwara people consume locusts almost daily, particularly the species Rhammatocerus schistocercoides, either hoppers in the rainy season or adults in the dry season. The locusts are toasted over charcoal and eaten as such, mixed with fruit juices, or added to cassava flour to make a kind of bread (Figure 3b) [55-57]. The examples could be increased as the practice was common in many countries and civilizations. 


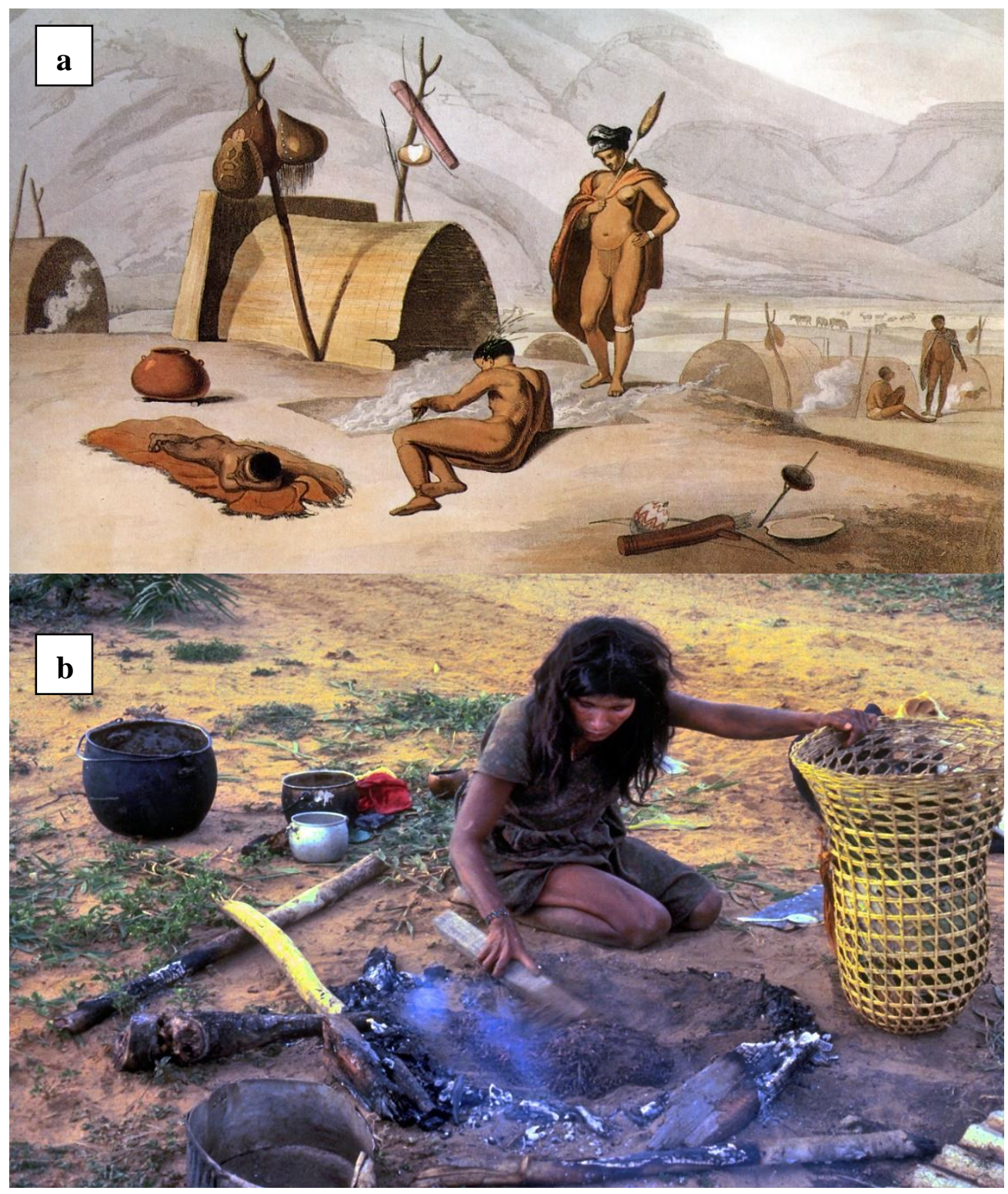

Figure 3. (a) 'Khoisan engaged in roasting grasshoppers on grills', a painting by Samuel Daniell, 1805. The Khoisan are the early indigenous peoples of southern Africa who traditionally ate insects in their everyday diet. (Reproduction from Suid-Afrikaanse in Beeld by A. Preston. Bion Books, South Africa (Copyright Commons)). (b) A Nambikwara woman in Mato Grosso (Brazil) toasting locusts (photographed by E. Setz, 1992).

Despite the role of entomophagy in the history and evolution of the human diet, nowadays, use of insects as food varies greatly across the world, yet its potential is great [58]. Many countries struggle with food shortages, with huge numbers of people dying from starvation every day. The FAO has estimated that to feed the global population in 2050, food production must increase by 70\% [59]. Locusts can serve as a source of animal protein, and their consumption should be promoted for environmental, health, and livelihoodrelated reasons, both social and economic [60]. However, there is often abhorrence or fear of entomophagy in many Western societies, a barrier related to cultural factors and history, as well as a lack of information on the possible effects of introducing locusts into food [61]. To conserve what natural habitats and associated biodiversity remain, as well as feed an already struggling human population, a change in attitude towards entomophagy in westernized societies is needed [62]. Nevertheless, locusts are regularly consumed 
by humans in Asia, Africa, and southern USA. In southeastern Asia, locusts are even being farmed for food and livestock feed [63]. Desert locusts in particular are a nutritious food source for humans, as they contain substantial proportions of proteins, fats, energy, and minerals. Furthermore, they metabolize ingested phytosterols into derivatives with potential health benefits for humans [64].

The combined weight of the 60 million adult locusts was $17,100 \mathrm{~kg}$. Their progenies were equally divided between weight categories of the five instar stages and together weighed 1,103,088 kg. Data from Wahed et al. [65] were used to calculate mineral content and chemical composition of $1 \mathrm{~km}^{2}$ of adult locusts and their progenies. The locusts they used were mass reared in Egypt; adults and nymphs were continually bred for many generations under laboratory conditions according to Vanden Broeck et al. [66]. These values were compared to three other studies on the nutrient content of adult Desert locusts, one study used specimens from commercial suppliers [67], another collected locusts from Kenya [64], and another from Sudan [63].

According to the mineral analyses of Wahed et al. [65], mineral content was always lower in adults than hoppers for phosphorus (8.744 and 9.135), potassium (673.278 and 782.696), calcium (3.38 and 5.07), and magnesium (1.356 and 1.824) mg/100 g. Compared to other studies, mineral contents of adult locusts were generally lower for most minerals, except for potassium, which varied between studies. The combined mineral weights for 1 $\mathrm{km}^{2}$ of adult Desert locusts and their progenies were: phosphorus, 102,270 g; potassium, 8,748,960 g, calcium, 56,510 g; and magnesium, 20,350 g (Table 5).

Table 5. Mineral content and chemical composition of $1 \mathrm{~km}^{2}$ adult Desert locusts and their progenies. Adult human recommended daily intake provided in last column.

\begin{tabular}{ccccc}
\hline $\begin{array}{c}\text { Factor } \\
\text { (g/km } \mathbf{2} \text { of Adults) }\end{array}$ & Adults & Hoppers & Combined & $\begin{array}{c}\text { Adult Recommended } \\
\text { Intake (g/d) }\end{array}$ \\
& & & & (WHO/FAO/UNU, 2004) \\
\hline Phosphorus (P) & 1500 & 100,770 & 102,270 & 0.7 \\
Potassium (K) & 115,130 & $8,633,830$ & $8,748,960$ & 4.7 \\
Calcium (Ca) & 580 & 55,930 & 56,510 & 1 to 1.3 (Avge: 1.15$)$ \\
Magnesium (Mg) & 230 & 20,120 & 20,350 & 0.22 to 0.26 (Avge: 0.24$)$ \\
Protein & $9,711,090$ & $727,155,610$ & $736,866,700$ & 46 (F); 56 (M) (Avge: 51$)$ \\
Fat & $4,928,220$ & $167,117,830$ & $172,046,050$ & 44 to 77 (Avge: 60.5) \\
Total Carbohydrate & 509,580 & $50,631,740$ & $51,141,320$ & 225 to 325 (Avge: 275$)$ \\
Fiber & $1,350,900$ & $87,143,950$ & $88,494,850$ & 25 to 30 (Avge: 27.5) \\
\hline
\end{tabular}

According to chemical content analyses on the Desert locust by Wahed et al. [65], hoppers contained more protein, total carbohydrate, and ash than adults. For adult locusts, these values are comparable to those reported from other studies $[63,64,67]$. Based on these values, 60 million swarming adult locusts and their progenies would comprise $736,866,700 \mathrm{~g}$ of protein (Table 5). The carbohydrate content of both hoppers $(4.59 \mathrm{~g} / 100 \mathrm{~g})$ and adult locusts $(2.98 \mathrm{~g} / 100 \mathrm{~g})$ was much lower than the recommended daily intake values ( 225 to $325 \mathrm{~g} / \mathrm{d}$ ) (Table 5). These low values are to be expected because edible insects generally are not good sources of carbohydrates [64]. Despite this, a $1 \mathrm{~km}^{2}$ area of adult locusts and their progeny would contain 51,141,320 g of carbohydrates (Table 5). Adults and hoppers had the same crude fiber content $(7.9 \mathrm{~g} / 100 \mathrm{~g})$, which was slightly higher than other reported values $[64,67]$. The combined fiber produced by a $1 \mathrm{~km}^{2}$ area of adult locusts and their hoppers is $88,494,850 \mathrm{~g}$. Crude fiber probably arises from locust chitin and plays an important role in human digestion [68]. Adult locusts had higher fat content $(28.82 \mathrm{~g} / 100 \mathrm{~g})$ than hoppers $(15.15 \mathrm{~g} / 100 \mathrm{~g})$, and values were within the range of other reported values $[61,62,65]$. A $1 \mathrm{~km}^{2}$ area of adult locusts and their progeny would comprise $172,046,050 \mathrm{~g}$ of fat (Table 5). Fat content can vary greatly between individuals, depending on age and diet. For humans, fats contribute to nutrition as an energy source, a supplier of essential fatty acids, and increase the palatability of foods by adding flavor $[64,67]$. 


\subsection{Putting Things into Perspective}

Throughout the world, rice and maize are among the most important crops for human consumption, and both are severely impacted by desert locust swarms [69,70]. Dobermann and Witt [71] conducted a survey of 207 rice farms in China, India, Indonesia, the Philippines, Thailand, and Vietnam. From the obtained values, the average grain yield was $5919 \mathrm{~kg} / \mathrm{ha}$, and average nitrogen, phosphorus, and potassium (NPK) uptakes were 117,18 , and $123 \mathrm{~kg} / \mathrm{ha}$, respectively. Values were based on one or two crops grown in 1995-1996 or 1997, giving a total sample size of 391. For maize, average plant density is 70,000 plants/ha (mostly varying from 60,000 to 80,000 ) [72-74], with a yield of around $9500 \mathrm{~kg} / \mathrm{ha}$ and average NPK uptakes of 609, 357, and $280 \mathrm{~kg} / \mathrm{ha}$, respectively [75].

The $\mathrm{N}$ mineralized from the frass and cadavers of a $1 \mathrm{~km}^{2}$ area (100 ha) of locusts and their progeny could meet the $\mathrm{N}$ uptake requirements of around 306 ha of rice crops and 59 ha of maize plants. The $\mathrm{P}$ and $\mathrm{K}$ released from the cadavers of locust adults and their offspring could individually meet the nutrient requirements of about 5682 ha (for $\mathrm{P}$ ) and 71,130 ha (for K) of rice crops and 286 ha (for P) and 31,246 ha (for K) of maize plants. When considering the uptake requirements of rice and maize plants for all three nutrients, the nutrients supplied by $1 \mathrm{~km}^{2}$ area of locusts and their progeny could result in a yield of approximately $1,811,214 \mathrm{~kg}$ of rice grain and $560,500 \mathrm{~kg}$ of maize grain.

Kenya is a country most severely affected by the recent (2019) locust breakout, with around 70,000 ha of agricultural damage. Due to progressive changes in eating habits, rice consumption has been increasing by up to $15 \%$ per year since its introduction in 1907 [76]. With an average per capita consumption of $20.6 \mathrm{~kg} / \mathrm{y}$, the rice yield resulting from the nutrients mineralized by $1 \mathrm{~km}^{2}$ area of locusts and their progenies could supply sufficient rice grain for about 87,900 Kenyans for a year. In Kenya, maize is the most important staple for calorie nutrition [77], with per capita consumption estimated at $114 \mathrm{~kg} / \mathrm{y}$ [78]. The maize yield resulting from the nutrients supplied by $1 \mathrm{~km}^{2}$ of locusts, and their offspring could provide sufficient maize grain for about 4900 Kenyans for a year [79].

With regards to meeting the dietary requirements of humans from consumption of locusts, 60 million adult locusts and their progeny would meet the following daily intake requirements: for phosphorus, 146,100 adults for a day or 400 adults for a year; for potassium, 1,861,480 adults for a day or 5096 adults for a year; for calcium, 49,145 adults for a day or 134 adults for a year; and for magnesium, 84,791 adults for a day or 232 adults for a year (Table 5).

The protein content of both life stages is greater than many conventional human foods, including chicken and beef [80]. Protein acquired from insects is of high quality, and consequently, the protein from the Desert locust is considered a good source of animal protein for humans [64]. Consumption of 100 adult or hopper Desert locusts will contribute over $100 \%$ of the recommended daily intake for adult females $(46 \mathrm{~g} / \mathrm{d})$ and males $(56 \mathrm{~g} / \mathrm{d}$ ) (Table 5). The protein from $1 \mathrm{~km}^{2}$ of adult locusts and their progeny would provide enough protein for $14,488,366$ people for a day or 39,584 people for a year, sufficient carbohydrates to meet the daily intake needs of around 186,000 people or the yearly requirements of approximately 500 people, the daily fiber needs of more than 3 million people or yearly requirements of about 9000 people, and comprise enough fat content for around 3 million adult humans for a day or 7800 people for a year (Table 5).

\section{Discussion}

Locust plagues have been referred to as the oldest entomological problem. These insects have directly affected settled agriculture from its very beginnings. The earliest known record of a locust was drawn on the wall of an Egyptian tomb, dating back to around 2400 BCE. The historical battle with locust infestations has also been widespread, with evidence from ancient Egyptian, Chinese, Hebrew, Roman, and Greek texts [81]. Despite years of experience, research, and technological advance, and even though invasions are now less frequent and more rapidly controlled [22,39], these locust plagues still wreak havoc, with the world currently facing one of the worst outbreaks in decades [82]. 
The negative impacts associated with locust swarms are well documented, particularly those affecting agricultural activities. Swarms can have a major impact on the food security and livelihoods of affected communities, particularly the poorest. Losses to crops and pasture can lead to severe food shortages, strong price movements in markets, insufficient availability of grazing areas, sale of animals at very low prices to meet household subsistence needs and to purchase feed for remaining animals, early transhumance of herds and strong tensions between transhumant pastoralists and local farmers, and large human migrations to urban areas [83]. Other economic consequences may occur at harvest, as grain may be contaminated with insect parts and downgraded to a feed grain sold at a lower price [84]. Furthermore, the negative income shock may have a long-term impact on the educational outcomes (school enrollment and completion) of children living in rural areas [85]. And of course, the widespread use of highly toxic chemical insecticides over large areas can have significant effects on the health of human populations, their livestock and food crops, as well as potential damage to local ecosystems and key wildlife [86,87].

However, locusts are not all bad, as they play a major role in nutrient cycling. Here, we focus on the ecological significance of locust swarms for nutrient transfer and cycling, providing quantitative evidence from one of the best investigated locusts, the Desert locust. Cycling of nutrients is a critical factor in the current era of great environmental change and soil deterioration. Today is also a time of high human population density and where means are being sought to procure alternative sources of protein other than traditional meat consumption. Locusts would seem to offer potential benefits.

Locust outbreaks undoubtedly affect ecosystem structure and functioning in many ways. However, while plants experience defoliation, they also gain nutrients, and as locusts move around, the nutrients are being shifted spatially. While the negative impacts of locusts are well documented, especially reduction in aboveground biomass due to feeding, the actual and potential benefits of locust swarms are seldom acknowledged. Here, we show that a $1 \mathrm{~km}^{2}$ area of Desert locusts could produce around 36,000 $\mathrm{kg}$ of mineralized nitrogen and 1,200,000 $\mathrm{kg}$ of mineralized carbon for redistribution within an ecosystem and across ecosystems.

Several authors show that locusts, and orthopterans in general, play an important trophic role [88], are stimulators of microbiological processes of decomposition and mineralisation of phytomass [89], can improve the productivity of grasslands in the long term [90], and in case of outbreak, can change considerably fluxes of some chemical elements in the herbaceous ecosystems [26]. Locust frass and cadavers are rich in nutrients, which are transferred to the soil via decomposition by microorganisms and fungi, absorbed by plants, increasing net ecosystem productivity [50] and ecosystem nutrient cycling through rapid mineralization rates of nitrogen and carbon. In one area, nutrients could potentially occur within the same season and promote recovery of the damaged crops or increase soil health to benefit crops for the next growing season [91]. However, as locusts also move far, and over many weeks and months, they are redistributing nutrients over space and time, which may directly benefit local farmers who would have suffered crop loss. Although the damage by locust swarms is devastating, the redistribution of nutrients could be from agricultural areas to ones that are nutrient poor with threatened natural vegetation. In this way, locusts could be viewed as conservationists of our ravaged natural ecosystems, as well as benefiting farmers in other locations at other times.

Locusts are a highly nutritious food source for humans and animals, as they contain significant proportions of proteins, fats, and minerals [64]. A $1 \mathrm{~km}^{2}$ area of Desert locusts can provide enough protein to support almost 40,000 people for a year. In many countries, locusts are already eaten every time an outbreak occurs, and yet, it has been suggested that rather than eating them, pesticides are used.

Some of the methods used to harvest locusts during outbreaks include collecting by hand, using large sweep nets, and pulling sheets over the vegetation they are roosting on or with machines that can suck them up [92]. After a Desert locust outbreak in Pakistan, 10 villages harvested $1275 \mathrm{~kg}$ of locusts in four days from a swarm of $5 \mathrm{~km}^{2}$. The locusts were 
first boiled, then dried in the sun for a day, after which they could be stored and used to make various appealing dishes, such as biryani, or eaten as a snack [93].

In the 1970s, the Bombay locust (Patanga succincta) was a huge problem in Thailand, feeding on sorghum and corn [94]. After pesticide application attempts were unsuccessful, a campaign was organized from 1978 to 1981 to harvest the locusts for consumption. This proved so successful that the locust no longer seems a problem in Thailand [94], although some argue that the data are inconclusive and that the locust may have been affected by a fungus that killed a large part of the population [1,41,95]. Alternatively, locusts can be used for feed or as fertilizer. An organization in Kenya paid farmers USD 0.45 per kg of locusts, which were dried and crushed into a powder that was used as an organic fertilizer or in animal feed [96]. The only serious risk associated with eating locusts is poisoning when they have been treated with pesticides [97]. However, recent developments have allowed for the synthesis of biopesticides, which use entomopathogenic fungi or protozoa as biocontrol methods. Many of these, such as various commercial strains of Metarhizium acridum, are of minimal risk to vertebrates and the environment [98]. Since locust outbreaks are intermittent, their use in human food can only be considered as an occasional food supplement when uncontrolled outbreaks develop into an invasion. This perspective also bears in mind however, that locust carcasses can be dried, ground, and stored for future needs.

We end on a note of caution. If there is extensive and intensive human consumption of locusts, might there be erosion of the ecological value of locusts, especially in terms of redistribution of plant nutrients? This would need to be a major research topic for the future. However, for now, it is better that humans eat locusts than kill them with harmful pesticides.

\section{Conclusions}

For many years, locusts have been viewed only in a negative light. Although they are responsible for devastating crop losses, they also play an important role in nutrient cycling. Due to the high concentration of nutrients in their bodies and frass, combined with the ability to disperse over long distances over time, locusts are important for the redistribution of nutrients across regions, often in arid nutrient-poor areas. This takes place among many locust and grasshopper species around the world. The effects can be so large that locust swarms can influence landscape-level ecological processes. Locusts can also be beneficial to humans, and their consumption should be used as a mitigation measure and to effectively prevent malnutrition, at least in times of locust outbreaks. Locust meal can be prepared from captured individuals, dried and ground, and then stored for precautionary use in times without locust plagues. However, there must be resolution and coordination among locust control practitioners using pesticides and people harvesting locusts as food to prevent poisoning from eating insects treated with pesticides. Future locust control strategies should consider a combination of biopesticides and collecting locusts for human consumption to the benefit of humanity and our natural ecosystems.

Supplementary Materials: The following are available online at https:/ / www.mdpi.com/article/10 .3390 /agronomy11091856/s1, Table S1: Main species of pest locusts and grasshoppers around the world today (modified from Lecoq and Zhang 2019).

Author Contributions: Conceptualization, M.J.S. and M.L.; Formal Analysis, G.J.K.; WritingOriginal Draft Preparation, G.J.K., M.J.S. and M.L.; Writing-Review and Editing, G.J.K., M.J.S. and M.L. All authors have read and agreed to the published version of the manuscript.

Funding: This research received no external funding.

Conflicts of Interest: The authors declare no conflict of interest. 


\section{References}

1. Haskell, P.T. International Locust Research and Control. J. R. Soc. Arts 1971, 119, 249-263.

2. Sayed, M.R. Locust and Its Signification in Ptolemaic Texts. J. Hist. Archaeol. Anthropol. Sci. 2018, 3, 584-588. [CrossRef]

3. McNeill, W.H. Plagues and Peoples; Anchor Books: New York, NY, USA, 1998.

4. Cullen, D.A.; Cease, A.J.; Latchininsky, A.V.; Ayali, A.; Berry, K.; Buhl, J.; De Keyser, R.; Foquet, B.; Hadrich, J.C.; Matheson, T.; et al. From molecules to management: Mechanisms and consequences of locust phase polyphenism. Adv. Insect Phys. 2017, 53, 167-285.

5. Pener, M.P.; Simpson, S.J. Locust Phase Polyphenism: An Update. Adv. Insect Physiol. 2009, 36, 1-272.

6. Applebaum, S.W.; Heifetz, Y. Density-Dependent Physiological Phase in Insects. Annu. Rev. Entomol. 1999, 44, 317-341. [CrossRef] [PubMed]

7. Song, H. Phylogenetic Perspectives on the Evolution of Locust Phase Polyphenism. J. Orthoptera Res. 2005, 14, 235-245. [CrossRef]

8. Song, H.; Moulton, M.J.; Hiatt, K.D.; Whiting, M.F. Uncovering Historical Signature of Mitochondrial DNA Hidden in the Nuclear Genome: The Biogeography of Schistocerca Revisited. Cladistics 2013, 29, 643-662. [CrossRef]

9. Chapuis, M.P.; Bazelet, C.S.; Blondin, L.; Foucart, A.; Vitalis, R.; Samways, M.J. Subspecific Taxonomy of the Desert Locust, Schistocerca gregaria (Orthoptera: Acrididae), Based on Molecular and Morphological Characters. Syst. Entomol. 2016, 41, 516-530. [CrossRef]

10. Rainey, R. Migration and Meteorology. Flight Behaviour and the Atmospheric Environment of Locusts and Other Migrant Pests; Oxford University Press: Oxford, UK, 1989.

11. Balança, G.; Gay, P.; Rachadi, T.; Lecoq, M. Interpretation of Recent Outbreaks of the Migratory Locust Locusta migratoria migratorioides (Reiche and Fairmaire, 1850) [Orthoptera, Acrididae] in Lake Chad Basin According to Rainfall Data. J. Orthoptera Res. 1999, 8, 83-92. [CrossRef]

12. Kennedy, J.S. The Behaviour of the Desert Locust (Schistocerca gregaria (Forsk.))(Orthopt.) in an Outbreak Centre. Trans. R. Entomol. Soc. Lond. 1939, 89, 385-542. [CrossRef]

13. Roffey, J.; Popov, G. Environmental and Behavioural Processes in a Desert Locust Outbreak. Nature 1968, 219, 446-450. [CrossRef]

14. Ji, R.; Xie, B.Y.; Li, D.M.; Li, Z.; Zeng, X.C. Relationships between Spatial Pattern of Locusta Migratoria Manilensis Eggpods and Soil Property Variability in Coastal Areas. Soil Biol. Biochem. 2007, 39, 1865-1869. [CrossRef]

15. Bouaïchi, A.; Simpson, S.J.; Roessingh, P. The Influence of Environmental Microstructure on the Behavioural Phase State and Distribution of the Desert Locust Schistocerca gregaria. Physiol. Entomol. 1996, 21, 247-256. [CrossRef]

16. Van Der Werf, W.; Woldewahid, G.; Van Huis, A.; Butrous, M.; Sykora, K. Plant Communities Can Predict the Distribution of Solitarious Desert Locust Schistocerca gregaria. J. Appl. Ecol. 2005, 42, 989-997. [CrossRef]

17. Uvarov, B. Grasshoppers and Locusts. A Handbook of General Acridology. Volume 1; Cambridge University Press: Cambridge, UK, 1966.

18. Uvarov, B. Grasshoppers and Locusts. A Handbook of General Acridology. Volume 2; Cambridge University Press: Cambridge, UK, 1977.

19. Hägele, B.F.; Simpson, S.J. The Influence of Mechanical, Visual and Contact Chemical Stimulation on the Behavioural Phase State of Solitarious Desert Locusts (Schistocerca gregaria). J. Insect Physiol. 2000, 46, 1295-1301. [CrossRef]

20. Rogers, S.M.; Matheson, T.; Despland, E.; Dodgson, T.; Burrows, M.; Simpson, S.J. Mechanosensory-Induced Behavioural Gregarization in the Desert Locust Schistocerca gregaria. J. Exp. Biol. 2003, 206, 3991-4002. [CrossRef]

21. Anstey, M.L.; Rogers, S.M.; Ott, S.R.; Burrows, M.; Simpson, S.J. Serotonin Mediates Behavioral Gregarization Underlying Swarm Formation in Desert Locusts. Science 2009, 323, 627-630. [CrossRef] [PubMed]

22. Zhang, L.; Lecoq, M.; Latchininsky, A.; Hunter, D. Locust and Grasshopper Management. Annu. Rev. Entomol. 2019, 64, 15-34. [CrossRef] [PubMed]

23. Modder, W. Control of the Variegated Grasshopper Zonocerus variegatus (L.) on Cassava. Afr. Crop. Sci. J. 1994, 2, 391-406.

24. Latchininsky, A.V. Moroccan Locust Dociostaurus maroccanus (Thunberg, 1815): A Faunistic Rarity or an Important Economic Pest? J. Insect Conserv. 1998, 2, 167-178. [CrossRef]

25. Skaf, R.M. Le Criquet marocain au Proche-Orient et sa grégarisation sous l'influence de l'homme. Bull. Soc. Ecol. 1972, 3, 247-325.

26. Sergeev, M.G. Ups and Downs of the Italian Locust (Calliptamus italicus L.) Populations in the Siberian Steppes: On the Horns of Dilemmas. Agronomy 2021, 11, 746. [CrossRef]

27. Cease, A.; Elser, J.; Ford, C.; Hao, S.; Kang, L.; Harrison, J. Heavy Livestock Grazing Promotes Locust Outbreaks by Lowering Plant Nitrogen Content. Science 2012, 335, 467-469. [CrossRef]

28. Deveson, E.D. Naturae Amator and the Grasshopper Infestations of South Australia's Early Years. Trans. R. Soc. S. Aust. 2012, 136, 1-15. [CrossRef]

29. Lecoq, M.; Sukirno. Drought and an exceptional outbreak of the oriental migratory locust, Locusta migratoria manilensis (Meyen 1835) in Indonesia (Orthoptera: Acrididae). J. Orthoptera Res. 1999, 8, 153-161. [CrossRef]

30. Dobson, H.M. Desert Locust Guidelines 4. Control; Food and Agriculture Organization of the United Nations (FAO): Rome, Italy, 2001.

31. FAO. Evaluation of field trials data on the efficacy and selectivity of insecticides on locusts and grasshoppers. In Proceedings of the Report to FAO by the Pesticide Referee Group Tenth Meeting, Gammarth, Tunisia, 10-12 December 2014; FAO: Rome, Italy, 1996.

32. Zhang, L.; Lecoq, M. Nosema locustae (Protozoa, Microsporidia), a Biological Agent for Locust and Grasshopper Control. Agronomy 2021, 11, 711. [CrossRef]

33. Lomer, C.J.; Bateman, R.P.; Johnson, D.L.; Langewald, J.; Thomas, M. Biological Control of Locusts and Grasshoppers. Annu. Rev. Entomol. 2001, 46, 667-702. [CrossRef] 
34. Hunter, D.M. Credibility of an IPM Approach for Locust and Grasshopper Control: The Australian Example. J. Orthoptera Res. 2010, 19, 133-137. [CrossRef]

35. Rachadi, T. Locust Control. Handbook; EU: Wageningen, The Netherlands, 2010.

36. Sharma, A. Locust Control Management: Moving from Traditional to New Technologies-An Empirical Analysis. Entomol. Ornithol. Herpetol. 2015, 4, 2161-2183.

37. Cressman, K. The Use of New Technologies in Desert Locust Early Warning. Outlooks Pest. Manag. 2008, 19, 55-59. [CrossRef]

38. Matthews, G.A. New Technology for Desert Locust Control. Agronomy 2021, 11, 1052. [CrossRef]

39. Simpson, S.J.; Raubenheimer, D.; Behmer, S.T.; Whitworth, A.; Wright, G.A. A Comparison of Nutritional Regulation in Solitariousand Gregarious-Phase Nymphs of the Desert Locust Schistocerca gregaria. J. Exp. Biol. 2002, 205, 121-129. [CrossRef] [PubMed]

40. Sword, G.A.; Lecoq, M.; Simpson, S.J. Phase Polyphenism and Preventative Locust Management. J. Insect Physiol. 2010, 56, 949-957. [CrossRef] [PubMed]

41. Van Huis, A. Harvesting Desert Locusts for Food and Feed May Contribute to Crop Protection but Will Not Suppress Upsurges and Plagues. J. Insects Food Feed 2021, 7, 245-248. [CrossRef]

42. Rainey, R.C. The Use of Insecticides against the Desert Locust. J. Sci. Food Agric. 1958, 9, 677-692. [CrossRef]

43. Symmons, P.M.; Cressman, K. Desert Locust Guidelines 1. Biology and Behaviour; FAO: Rome, Italy, 2001.

44. Peng, W.; Ma, N.L.; Zhang, D.; Zhou, Q.; Yue, X.; Khoo, S.C.; Yang, H.; Guan, R.; Chen, H.; Zhang, X.; et al. A Review of Historical and Recent Locust Outbreaks: Links to Global Warming, Food Security and Mitigation Strategies. Environ. Res. 2020, 191, 110046. [CrossRef] [PubMed]

45. Krogh, A.; Weis-Fogh, T. A Roundabout for Studying Sustained Flight of Locusts. J. Exp. Biol. 1952, 29, 211-219. [CrossRef]

46. Maeno, K.; Tanaka, S. Phase-Specific Responses to Different Qualities of Food in the Desert Locust, Schistocerca gregaria: Developmental, Morphological and Reproductive Characteristics. J. Insect Physiol. 2011, 57, 514-520. [CrossRef]

47. Fielding, D.J.; Trainor, E.; Zhang, M. Diet Influences Rates of Carbon and Nitrogen Mineralization from Decomposing Grasshopper Frass and Cadavers. Biol. Fertil. Soils 2013, 49, 537-544. [CrossRef]

48. Reynolds, B.C.; Hunter, M.D.; Crossley, D.A., Jr. Effects of canopy herbivory on nutrient cycling in a Northern Hardwood Forest in Western North Carolina. Selbyana 2000, 21, 74-78.

49. Fielding, D.J.; Conn, J.S. Feeding Preference for and Impact on an Invasive Weed (Crepis tectorum) by a Native, Generalist Insect Herbivore, Melanoplus borealis (Orthoptera: Acrididae). Ecol. Popul. Biol. Ann. Entomol. Soc. Am. 2011, 104, 1303-1308. [CrossRef]

50. Lovett, G.M.; Christenson, L.M.; Groffman, P.M.; Jones, C.G.; Hart, J.E.; Mitchell, M.J. Insect Defoliation and Nitrogen Cycling in Forests. Bioscience 2002, 52, 335-341. [CrossRef]

51. Hill, L.; Mordue, W.; Highnam, K.C. The Endocrine System, Frontal Ganglion, and Feeding during Maturation in the Female Desert Locust. J. Insect Physiol. 1966, 12, 1197-1208. [CrossRef]

52. Norris, M.J. Group Effects on Feeding in Adult Males of the Desert Locust, Schistocerca gregaria (Forsk.), in Relation to Sexual Maturation. Bull. Entomol. Res. 1961, 51, 731-753. [CrossRef]

53. Evans, J.; Alemu, M.H.; Flore, R.; Frøst, M.B.; Halloran, A.; Jensen, A.B.; Maciel-Vergara, G.; Meyer-Rochow, V.B.; MünkeSvendsen, C.; Olsen, S.B.; et al. “Entomophagy": An Evolving Terminology in Need of Review. J. Insects Food Feed 2015, 1, $293-305$. [CrossRef]

54. Samways, M.J. Approaches and Perspectives in Insect Species Conservation. In Insect Conservation: A Global Synthesis; CABI: Wallingford, UK, 2019; pp. 113-151.

55. Lévi-Strauss, C. La vie familiale et sociale des indiens Nambikwara. J. Soc. Am. 1948, 37, 1-132. [CrossRef]

56. Lecoq, M.; Pierozzi, I. Rhammatocerus schistocercoides Locust Outbreaks in Mato Grosso (Brazil): A Long-Standing Phenomenon. Int. J. Sustain. Dev. World Ecol. 1995, 2, 45-53. [CrossRef]

57. Setz, E.Z.F. Animals in the Nambiquara Diet: Methods of Collection and Processing. J. Ethnobiol. 1991, 11, 1-22.

58. Raubenheimer, D.; Rothman, J.M. Nutritional Ecology of Entomophagy in Humans and Other Primates. Annu. Rev. Entomol. 2013, 58, 141-160. [CrossRef]

59. Lensvelt, E.J.S.; Steenbekkers, L.P.A. Exploring Consumer Acceptance of Entomophagy: A Survey and Experiment in Australia and the Netherlands. Ecol. Food Nutr. 2014, 53, 543-561. [CrossRef] [PubMed]

60. Van Huis, A. Potential of Insects as Food and Feed in Assuring Food Security. Annu. Rev. Entomol. 2013, 58, 563-583. [CrossRef]

61. Ochiai, M.; Inada, M.; Horiguchi, S. Nutritional and safety evaluation of locust (Caelifera) powder as a novel food material. J. Food Sci. 2020, 85, 279-288. [CrossRef] [PubMed]

62. Yen, A.L. Edible Insects: Traditional Knowledge or Western Phobia? Entomol. Res. 2009, 39, 289-298. [CrossRef]

63. Mariod, A.A. African Edible Insects as Alternative Source of Food, Oil, Protein and Bioactive Components; Springer Nature: Cham, Switzerland, 2020.

64. Kinyuru, J.N. Nutrient Content and Lipid Characteristics of Desert Locust (Schistoscerca gregaria) Swarm in Kenya. Int. J. Trop. Insect Sci. 2020, 41, 1993-1999. [CrossRef]

65. Wahed, A.E.; Samira, M.N.; Ahmad, A.F. Variations in Chemical Composition Value of Adults and Nymphs Desert Locust, Schistocerca gregaria Forskål (Orthoptera: Acrididae). J. Plant Prot. Pathol. 2019, 10, 677-681.

66. Vanden Broeck, J.; Chiou, S.J.; Schoofs, L.; Hamdaoui, A.; Vandenbussche, F.; Simonet, G.; Wataleb, S.; De Loof, A. Cloning of Two CDNAs Encoding Three Small Serine Protease Inhibiting Peptides from the Desert Locust Schistocerca gregaria and Analysis of Tissue-Dependent and Stage-Dependent Expression. Eur. J. Biochem. 1998, 254, 90-95. [CrossRef] 
67. Zielińska, E.; Baraniak, B.; Karaś, M.; Rybczyńska, K.; Jakubczyk, A. Selected Species of Edible Insects as a Source of Nutrient Composition. Food Res. Int. 2015, 77, 460-466. [CrossRef]

68. Badanaro, F.; Amevoin, K.; Lamboni, C.; Amouzou, K. Edible Cirina Forda (Westwood, 1849) (Lepidoptera: Saturniidae) Caterpillar among Moba People of the Savannah Region in North Togo: From Collector to Consumer. Asian J. Appl. Sci. Eng. 2014, 3, 13. [CrossRef]

69. Musuna, A.C.Z. Cereal Crop Losses Caused by Locusts in Eastern, Central and Southern Africa Region. Int. J. Trop. Insect Sci. 1988, 9, 701-707. [CrossRef]

70. Tandzi, L.N.; Mutengwa, C.S. Estimation of Maize (Zea mays L.) Yield Per Harvest Area: Appropriate Methods. Agronomy 2020, 10, 29. [CrossRef]

71. Dobermann, A.; Witt, C. The Potential Impact of Crop. Intensification on Carbon and Nitrogen Cycling in Intensive Rice Systems; International Rice Research Institute: Los Baños, Philippines, 2000.

72. Abuzar, M.R.; Sadozai, G.U.; Baloch, M.S.; Baloch, A.A.; Shah, I.H.; Javaid, T.; Hussain, N. Effect of Plant Population Densities on Yield of Maize. J. Anim. Plant Sci. 2011, 21, 692-695.

73. Hou, P.; Liu, Y.; Liu, W.; Liu, G.; Xie, R.; Wang, K.; Ming, B.; Wang, Y.; Zhao, R.; Zhang, W.; et al. How to Increase Maize Production without Extra Nitrogen Input. Resour. Conserv. Recycl. 2020, 160, 104913. [CrossRef]

74. Shao, H.; Xia, T.; Wu, D.; Chen, F.; Mi, G. Root Growth and Root System Architecture of Field-Grown Maize in Response to High Planting Density. Plant Soil 2018, 430, 395-411. [CrossRef]

75. Du Plessis, J. Maize Production; Department of Agriculture: Pretoria, South Africa, 2003.

76. FAO. Rice Consumption Per Capita in Kenya. Available online: https://www.helgilibrary.com/indicators/rice-consumptionper-capita/kenya/ (accessed on 26 July 2021).

77. Marenya, P.P.; Wanyama, R.; Alemu, S.; Woyengo, V. Trait Preference Trade-Offs among Maize Farmers in Western Kenya. Heliyon 2021, 7, e06389. [CrossRef] [PubMed]

78. MoALF. Agricultural Sector Transformation \& Growth Strategy 2019-2029. Available online: https://www.kilimodata. developlocal.org (accessed on 26 July 2021).

79. CARD. Rice for Africa-Kenya. Available online: https://riceforafrica.net/card-countries/group-1-countries/kenya/kenya, -march-2021 (accessed on 26 July 2021).

80. Rumpold, B.A.; Schlüter, O.K. Nutritional Composition and Safety Aspects of Edible Insects. Mol. Nutr. Food Res. 2013, 57, 802-823. [CrossRef] [PubMed]

81. Uvarov, B. The Locust Plague. J. R. Soc. Arts 1942, 91, 109-118. [CrossRef]

82. Kumar, P.S.; Shukla, G.; Panwar, P.; Chakravarty, S. Locusts Plague: An Emerging Threat to India. Curr. Sci. 2021, 120, 10.

83. Brader, L.; DJibo, H.; Faya, F.G.; Ghaout, S.; Lazar, M.; Luzietoso, P.N.; Ould Babah, M.A. Towards a More Effective Response to Desert Locusts and Their Impacts on Food Security, Livelihood and Poverty; FAO: Rome, Italy, 2006.

84. Onyango, A. The Public Health Implication of the 2020 Locust Invasion in East Africa. Available online: https: / / globalhealth. euclid.int/the-public-health-implication-of-the-2020-locust-invasion-in-east-africa / (accessed on 27 July 2021).

85. De Vreyer, P.; Guilbert, N.; Mesple-Somps, S. Impact of Natural Disasters on Education Outcomes: Evidence from the 1987-89 Locust Plague in Mali. J. Afr. Econ. 2015, 24, 57-100. [CrossRef]

86. Everts, J.W.; Ba, L. Environmental Effects of Locust Control: State of the Art and Perspectives. New Strateg. Locust Control. 1997, 331-336. [CrossRef]

87. Peveling, R. Environmental Conservation and Locust Control-Possible Conflicts and Solutions. J. Orthoptera Res. 2001, 10, 171-187. [CrossRef]

88. Stebaev, I.V.; Gukasian, A.B. Orthoptera (Tettigonoidea and Acrididae) as stimulators of microbiological processes of decomposition and mineralization of phytomass in the meadow steppes of West Siberia. Zool. Zh. 1963, 42, $216-221$.

89. Gandar, M.V. The dynamics and trophic ecology of grasshoppers (Acridoidea) in a South African savanna. Oecologia 1982, 54, 370-378. [CrossRef] [PubMed]

90. Belovsky, G.E. Do grasshoppers diminish? In Grasshoppers and Grassland Health: Managing Grasshopper Outbreaks without Risking Environmental Disaster; Lockwood, J.A., Latchininsky, A.V., Sergeev, M.G., Eds.; Kluwer Academic Publishers: Dordrecht, The Netherlands; Boston, MA, USA; London, UK, 2000; pp. 7-29.

91. Song, J.; Wu, D.; Shao, P.; Hui, D.; Wan, S. Ecosystem Carbon Exchange in Response to Locust Outbreaks in a Temperate Steppe. Oecologia 2015, 1, 579-590. [CrossRef] [PubMed]

92. Van Huis, A. Insect Pests as Food and Feed. J. Insects Food Feed 2020, 6, 327-331. [CrossRef]

93. Samejo, A.A.; Sultana, R.; Kumar, S.; Soomro, S. Could Entomophagy Be an Effective Mitigation Measure in Desert Locust Management? Agronomy 2021, 11, 455. [CrossRef]

94. Chen, P.; Wongsiri, S.; Jamyanya, T.; Rinderer, T.; Vongsamanode, S.; Matsuka, M.; Sylvester, A.; Oldroyd, B. Honey Bees and Other Edible Insects Used as Human Food in Thailand. Am. Entomol. 1998, 44, 24-29. [CrossRef]

95. Samšiňáková, A.; Purrini, K. Über Eine Natürliche Infektion Der Heuschrecke, Patanga Succincta Durch Den Pilz Metarhizium anisopliae in Thailand. J. Appl. Entomol. 1986, 102, 273-277. [CrossRef] 
96. Ratner, B. Farmers Fight Back: Making Animal Feed from a Locust Plague. Available online: https://widerimage.reuters.com/ story / farmersfight-back-making-animal-feed-from-a-locust-plague (accessed on 26 July 2021).

97. Saeed, T.; Abu Dagga, F.; Saraf, M. Analysis of Residual Pesticides Present in Edible Locusts Captured in Kuwait. Arab Gulf J. Sci. Res. 1993, 11, 1-5.

98. Zimmermann, G. Review on Safety of the Entomopathogenic Fungus Metarhizium anisopliae. Biocontrol Sci. Technol. 2007, 17, 879-920. [CrossRef] 